\title{
The Traditional Religion of the Dayak in West Kalimantan: Analysis of J.U. Lontaan's Monograph
}

\author{
M. Ikhsan Tanggok ${ }^{\mathrm{a} *}$, Muhammad Rifqi Hawari ${ }^{\mathrm{b}}$ \\ ${ }^{a}$ Syarif Hidayatullah State Islamic University Jakarta, Indonesia \\ ${ }^{\mathrm{b}}$ Sunan Kalijaga State Islamic University, Yogyakarta, Indonesia \\ *corresponding author: ikhsan.tanggok@uinjkt.ac.id \\ Received: 5-3-2021; Revised: 27-4-2021; Accepted: 29-4-2021 \\ DOI: $10.31291 / \mathrm{hn} . v 10 \mathrm{i} 1.597$
}

\begin{abstract}
The aim of this paper is to explain Lontaan's views on the religious beliefs of the Dayak people in West Kalimantan as set forth in his book The History of Customary Laws and Traditions of West Kalimantan. It concentrates on the concept of traditional Dayak religion in Lontaan's work, which is still developing today even though the Dayak have embraced religions foreign to their island. In understanding, examining and explaining Lontaan's monograph, this paper uses a descriptive hermeneutical method. The source of this paper is the book The History of Customary Laws and Traditions of West Kalimantan by Lontaan. The data of this paper is Lontaan's field observations and interviews involving religious and traditional figures in West Kalimantan, which he compiled in The History of Customary Laws and Traditions of West Kalimantan forty-five years ago. The focus of this paper is the traditional Dayak religion (Kaharingan) and concerns the beliefs in God, spirits and ancestral spirits that it comprises. Based on the results of our research, it is clear that Lontaan succeeds in showing that the Dayaks' beliefs about spirits or gods and ancestral spirits can affect their daily lives. To connect with God, spirits and ancestral spirits, the Dayak hold various ceremonies. In contrast to other works on Dayak, Lontaan not only studied one of the Dayak tribes, but also examined the culture and religious beliefs of the Dayak Kenayatn, Kayan, Maayan and other Dayak tribes in West Kalimantan and its customs compared to each other.
\end{abstract}

Keywords: Dayak people; spirits or gods; ancestors; life after death; ritual 


\begin{abstract}
Abstrak
Tulisan ini bertujuan untuk menjelaskan pandangan Lontaan tentang keyakinan keagamaan masyarakat Dayak di Kalimantan Barat (Kalbar). Pandangan lontaan itu terdapat dalam karyanya yang berjudul "Sejarah Hukum Adat dan Adat Istiadat Kalimantan Barat." Masalah yang dibahas dalam tulisan ini adalah konsep agama tradisional orang Dayak dalam karya Lontaan yang masih tetap berkembang hingga sekarang meskipun mereka sudah menganut agama yang datang dari luar. Dalam memahami, mengkaji, dan menjelaskan karya Lontaan, tulisan ini menggunakan metode deskriptif hermeneutika. Sumber dari tulisan ini adalah buku Sejarah Hukum Adat dan Adat Istiadat Kalimantan Barat yang ditulis oleh Lontaan. Data tulisan ini berupa tulisan hasil pengamatan lapangan dan wawancara yang dilakukan oleh Lontaan tehadap tokoh-tokoh agama dan adat di Kalimantan Barat yang dia tulisan dalam bentuk buku empat puluh lima tahun lalu yang terkait dengan masalah penelitian. Fokus tulisan ini adalah agama tradisional orang Dayak (Kaharingan) yang isinya berhubungan dengan keyakinan orang Dayak terhadap Tuhan, roh-roh dan roh-roh leluhur. Berdasarkan hasil penelitian, Lontaan berhasil menggambarkan keyakinan orang Dayak tentang roh-roh (ilah-ilah) dan roh-roh leluhur yang dapat mempengaruhi kehidupan mereka sehari-hari. Untuk berhubungan dengan Tuhan, roh-roh dan roh-roh leluhur, mereka mengadakan berbagai upacara. Berbeda dengan karya-karya lain tentang Dayak, Lontaan tidak hanya mengkaji salah satu suku bangsa Dayak, tapi juga mengkaji kebudayaan dan keyakinan keagamaan orang Dayak Kenayan, Kayan, Maayan dan suku-suku Dayak yang lain di Kalimantan Barat dan adat-istiadatnya dia bandingkan satu dengan yang lainnya.
\end{abstract}

Kata Kunci: Orang Dayak; roh-roh atau ilah-ilah; leluhur; kehidupan setelah kematian; ritual

\title{
Introduction
}

This article aims to present that Lontaan's (1975) monograph The History of Customary Laws and Traditions of West Kalimantan should not only be considered historical for its historical narration of different ethnic groups and their kingdoms, but also for its anthropological description of the culture, customs and religious life of the Dayak in West Kalimantan. Before exploring Lontaan's accounts on the religious beliefs of the Dayak in West Kalimantan, we examined the conceptions of religion and ceremony by some experts on Religious Studies whose studies are related to the present article. Indeed, 
religious beliefs and ceremonies are the main subjects under discussion in this article. One of the most well-known American anthropologists, Clifford Geertz who studied Javanese religiosity in the early 1960s, contend that religion is a system of symbols that functions to calm one's mood and strong motivations, which otherwise can dominate human being and last a long time. This can be achieved by forming concepts or beliefs about the general order of human existence and society, and by portraying them as if they are real or factual so that one's moods and motivations can be managed (Geertz 1960). In contrast, Havilland (1993:193) sees religion as a belief and a pattern of behavior that humans use to resolute important problems that cannot be solved through technology or the organizational techniques they are familiar with.

Unlike both Geetz and Haviland, Wallace (1966:107) defines religion as "a set of ceremonies that are given mythical rationality, and which mobilize supernatural forces with the intention of achieving or preventing a change in circumstances in humans or nature." Havilland (1993: 25) asserts that religion contains a recognition that if humans cannot solve the problems they face, those problems can cause them anxiety, which they then try to overcome by manipulating the spirits and supernatural powers they believe can assist them. They do this by means of religious ceremonies, which Wallace considers to be the main phenomenon of religion or "religion in action". Based on Wallace's view, religion can be conceived as a belief and a pattern of behavior that humans use to control the aspects of the universe that they can (Havilland 1993: 28). Controlling these aspects of the universe can be accomplished through ceremonies which are viewed as a means for connecting the visible world and invisible world (spirit 
The Traditional Religion...

realm) and reviving the severed connection between the living and the dead (Tanggok 2005: 104).

If religion is inseparable from ceremony, then it is also inseparable from a belief system. As Suparlan (1991:19) states, belief systems cannot be divorced from the cosmology or the ways people understand their society and the world they define. If the belief system is inseparable from the ceremony, then the ceremony is also inseparable from the ceremonial instruments or sacrifices offered to spirits during the course of it (Radam 1987: 30). When the offerings provided in the ceremony do not accord with the pleasures of the ancestors and gods, the latter will become angry so that family members and society in general are punished (Tanggok 2017: 25). Thus, there is a strong connection between the belief system, ceremony and instruments used or offerings made during the ceremony.

Turner (1974:55) states that regardless of whether the ceremony serves as a method for pleasing the hearts of spirits or as a means for curing illnesses, all of this is inseparable from religious phenomena. The same goes to those of religions originating from divine revelation or those belonging to ethnic communities occupying rural areas in Indonesia, which they employ as a guide in their daily lives (Wallace 1966:77). Thus, the beliefs of a person or group in their divinity, spirits and ancestral spirits can be recognized in the actions they perform in ceremonies.

In line with the meaning of ceremony as formulated by Wallace and Haviland, Keesing (1975) considers ceremony to be a pattern of behavior that is creatively designed and repeated by humankind, mostly in a collective manner and shaped by culture. Ceremonies are also often interpreted as religious ceremonies; ornate behaviors are 
seen as sacred or holy. The ornate behavior Keesing refers to can also be interpreted as being full of symbolism and meanings as well as containing values used as references in human life.

The relationship between religious belief and rituals is also found in Lontaan's work. The aim of this paper is to discuss Lontaan's views on the religious beliefs of the Dayak people as set forth in his book The History of Customary Laws and Traditions of West Kalimantan. The term Dayak is the name given by the inhabitants of the Kalimantan coast to the inhabitants of the interior or mountains (Suminto 2017: 5166). This Lontaan's (1975) describes at length the traditional religion of the Dayak, which thought to have been influenced by Hinduism and Islam. Although it has been forty-six years since Lontaan's book was published, the customs and traditional religion of the Dayak are still practiced today. The term Dayak as explained by Heidhues (2003: 8) refers to indigenous non-Muslims who have a different culture from other ethnic groups in West Kalimantan. While Lontaan's monograph discusses many aspects of the life of the tribes in West Kalimantan including the Dayak's, many writings about the Dayak tribes and their cultures, such as those by Radam (1987), Danandjaja (in Koentjaraningrat 1993), Sulistyowati (2020), Darmadi (2017) and Saefuddin (2019) do not include Lontaan's work in their papers. Thus, despite being published nearly half a century ago, Lontaan's monograph is still little known amongst scholars. This is one of the reasons to put forwards Lontaan's fundamental works to the scholarly community through this paper. This paper describes Lontaan's conceptions of the traditional Dayak religion or religious structure of the Dayak community which comprises the concepts of God, spirits, and ancestral spirits, as well as eschatology. 
J.U. Lontaan, the author of the monograph under study was born in Minahasa, North Sulawesi but lived and worked as a civil servant in Pontianak, West Kalimantan. Lontaan is one of the clan names in the district of Minahasa, North Sulawesi. The book does not supply his dates of birth or death. During his employment in Pontianak, he frequently visited Dayak areas throughout West Kalimantan and conducted research on the customary laws and traditions of the West Kalimantan people. One of the places he visited was the village of Lingga that is home to Dayak Kendayan people where he conducted interviews with the village head, Derani Ishak. One of Lontaan's motivations for writing his book was to introduce the customary laws and ancestral traditions that Lingga people still follow and continue in their daily lives. Lontaan's book was selected as the research data, because this book is one among many sources of the local cultural heritage, which people may have forgotten or ignored. The present study on Lontaan's monograph is relevant, particularly for this Heritage of Nusantara Journals for some rationales. One, the book matches the scope of the journal, which is religious studies. Two, a revisit to Lontaan's descriptions of Dayak beliefs about the supernatural world and Dayak customs is essential, especially in the era of rapid development of information and communication technologies. As the wave of newness brought by the internet reaches remotes villages, many locals started to forget or ignore their own native cultures and glorify foreign/new cultures instead.

\section{Method}

The research objective of this article is to describe, interpret, and understand Lontaan's discourse on Dayak religious beliefs. The data sources from Lontaan's book The History of Customary Laws and 
Traditions of West Kalimantan which were collected through noninteractive techniques, including content analysis of documents and books. The data itself is Lontaan's descriptions and understandings of Dayak religious beliefs. Data analysis includes some procedures such as rereading books, collecting and studying theories related to research, and analyzing them (Ghofur 2014 in Orong 2020: 165-193). In-depth data analysis was performed in order to comprehend the concept of Dayak diversity contained in Lontaan's book. The stages of analysis include: (1) reading the text closely and repeatedly to obtain a comprehensive understanding and overview of it, (2) interpreting all of the data, and (3) drawing conclusions.

In order to understand and explain this Lontaan's work, we employed a hermeneutical approach, particularly in exploring the people beliefs about spirits, ancestral spirits and God that influence their lives. The original meaning of hermeneutic is the interpretation of the sacred texts. It has been extended within philosophy and the social sciences to mean the interpretation of or the search for meaning in texts, in human existence, in society, and so on. The philosopher Martin Heidegger employed the term to mean the understanding of the word as the object of human thought and action (Smith 2003:136). In general, hermeneutics is defined as "the process of changing a situation of incomprehension into [one of] understanding" (Sumaryono 1996: 24).

\section{Literature Review}

Apart from Lontaan (1975) account of Dayak religious life including beliefs in God, spirits and ancestral spirits, several authors have tried to describe the concepts of belief amongst the Dayak in varied concerns the issues being addressed. I have not come across any scholarly work 
The Traditional Religion...

that specifically discusses Lontaan's book. Some scholars merely cited some of the information and opinions contained in Lontaan's monograph without acknowledgment to the author. Nonetheless, there are several articles and books about the Dayak that could be related to Lontaan's work. The first is an article by Yusriadi (2017:1-6) that discusses "Identitas Dayak dan Melayu di Kalimantan Barat (Dayak and Malay identity in West Kalimantan). He contends that today's various Dayak and Malay organizations have emerged. Dayak individuals who have converted to Islam have also created their own organizations representing Dayak Muslims. All of these organizations express their respective identities, and they are often used to strengthen political support if one of the tribe members becomes a local leader and a member of the Local People's Representative Council (Dewan Perwakilan Rakyat Daerah). In the conclusion to his article, Yusriadi explains that the Dayak and Malay are the two major groups in West Kalimantan marked by differences in religion. Muslims (especially native ones) in West Kalimantan were categorized as Malays, while non-Muslim indigenous people were called Dayak. While the Malay identity has been used in earlier times and is widely accepted in West Kalimantan, the Dayak identity was used and accepted only later on. Although Yusriadi thus discusses the Dayak, he did not focus on their religious beliefs. The connection of his article to Lontaan's book pertains on the view that sees Dayak as one tribe in West Kalimantan.

The second article is by Sulistyowati (Sulistyowati 2020: 185-198) entitled, "Wujud Budaya Masyarakat Dayak Meratus pada Novel Catatan Ayah tentang Cintanya kepada Ibu Karya Sandi Filry dan Kontribusinya terhadap Pembentukan Karakter Generasi Milenial," (The Existence of the Culture of the Meratus Dayak Community in the Novel Father's Notes about His Love for Mother by Sandi Filry and Its

8 VOL. 10 NO. 1 JUNE 2021 
Contribution to the Character Development of Millennial Generation).

Sulistyowati examines Sandi Firly's novel about the existence of Dayak Meratus culture residing in South Kalimantan. According to Sulistyowati, Dayak Meratus people strongly believe in the power of the balian (shaman). Sulistyowati considers that Firly was quite creative in his portrayal of Dayak Meratus beliefs about balian in the form of a story. These Dayak believe that a balian has an extraordinary ability to cure illnesses. Simply by holding the body of a sick person, balian can make the disease quickly subside or disappear. Sulistyowati concludes that the ideal cultural form is a custom or tradition that has been continuously maintained from generation to generation and thus today still comprises systems of belief, ritual and ceremonial tools. Although Sulistyowati describes the belief system of one Dayak tribe in South Kalimantan, she does not explain more broadly on Dayak beliefs about spirits, ancestral spirits and God, which are deeply studied in Lontaan's work. Furthermore, she details only the Dayak beliefs about the balian who is merely capable of curing sick people. Lontaan's work, in contrast, emphasizes the study of beliefs in spirits, ancestral spirits and God.

The third article is by Darmadi (2017) entitled, "Dayak and Their Daily Life." At one point, he mentions that based on a common belief and information that is spokenly spread, the ancestors of the Dayak originate from the seventh heaven. He also cites Lontaan's opinions, especially his division of the Dayak ethnic group into 405 tribes. However, in my view, Darmadi offers very little description of Lontaan's research. He writes more about the daily life of contemporary Dayak, covering such topics as traditional Dayak clothing, the red bowl (a symbol of the beginning of war), the sword, 
The Traditional Religion...

and spirituality. According to Darmadi, the Dayak possesses the capacity to locate an enemy through the power of a bird ruled by Manajah Atang (a type of shaman). The difference between Darmadi's piece and Lontaan's book is that Darmadi does not examine Dayak religious beliefs.

The fourth article is by Saefuddin (2019: 253-269) entitled, "Kearifan Tradisi Masyarakat Dayak Deah di Kalimantan Selatan," (Traditional Wisdom of the Dayak Deah Community in South Kalimantan). The problem engaged in this study is the nature of the traditional wisdom of the Dayak Deah community in South Kalimantan, and Saefuddin's research objective is to reveal the form of this traditional wisdom. He writes about the traditions of childbirth, marriage and death. The article concludes that the Dayak Deah still preserve traditional wisdom such as, (1) the tradition of giving birth to a baby still includes the involvement of a midwife or shaman (dukun). In addition, there are other traditional practices, such as hanging the mother's placenta from a tree and cutting it with a type of knife made from bamboo skin (sembilu). They do it to show that human beings are inseparable from nature, (2) the tradition of marriage is still maintained by the families of the bride and groom, who must both know the origin of their offsprings, and (3) the tradition of paying a penalty if the bride or groom fails to correctly narrate the family tree of his/her partner with the purpose to maintain the honor of family status. The difference between Saefuddin's article and Lontaan's book is that Saefuddin does not explain Dayak religious beliefs. The similarity between two works is that they both discuss local Dayak culture well preserved until today. These works are very useful as references for understanding Lontaan's book. 
Apart from the several articles describing Dayak above, there are two books which are considered to be related to Lontaan's work, such as books written by Rutter (2017) and Radam (1987). Radam in his work entitled "Religi Orang Bukit" (Religion of the Hill People) said that the Dayak Nganju who live in the mountains of South Kalimantan also maintain the existence of gods who control and sustain the human body, their houses and tools. Additionally, flora, fauna and objects are deemed sacred. All of these gods have the same position and thus human beings, nature, plants, mountains and rivers are all equal. They are called subordinate or assistant gods of higher gods (Radam 1987: 203). To connect with them, the Bukit people usually conduct ceremonies.

Besides Radam, Rutter, a historian from England also wrote about Dayak Dusun and Dayak Marut in North Kalimantan. In his work entitled "Sejarah Kalimantan" (British North Borneo) which was then translated into Indonesian under the title "The History of Kalimantan." In his book he explains Dayak Dusun and Dayak Marut people (i.e. branches of a Dayak tribe) in North Kalimantan also believe in a supreme god they call Kinaringan. Kinaringan is believed to have a wife named Munsummundok and a son named Towardakan. Even though these deities have human-like attributes, they are omnipotent and thought to live somewhere in the sky. The Dusun and Murut believe that the deities created the world and are responsible for it. People believe that there are gods of prosperity who can grant prosperity to humans, and therefore humans must be able to make peace with them if their lives are to be prosperous (Rutter 2017: 387). The understanding of heaven as the final abode of the spirits of the deceased also develops amongst the Bukit people in South Kalimantan 
The Traditional Religion...

and Kedayan Dayak in West Kalimantan. Thus, the belief system (involving the great creator and preserver, ancestral spirits, spirits and gods), ceremonial tools, ceremonies and ceremony leaders are related to one another and belong to all religions that come from outside as well as ethnic religions that exist amongst primitive societies, especially the Dayak community in West Kalimantan. These three works, like Radam's, Lutter's and Lontaan's have similarities in seeing religious beliefs in Dayak society in Kalimantan. The difference is that the three of them researched different Dayak tribes, Radam researched Dayak Bukit, Rutter researched Dayak Dusun and Murut, and Lontaan researched on Dayak Kendayan, Benawas, Bunut, Taman and Punan. Besides the Dayak tribes in South and West Kalimantan, there is a Dayak tribe also quite well known in Central Kalimantan, the name is the Dayak Ngaju tribe. Their religious beliefs are not much different from other Dayak tribes.

Lontaan seems to have felt that he had a moral responsibility to write about the customs of the Dayak people in West Kalimantan and their religious beliefs. He saw how important it is to understand the customs in which the religious beliefs of the Dayak are incorporated in order to study them more deeply. Studying and understanding the customs and traditional religion of a local community, especially one in West Kalimantan, means that we respect their customs and religion and ultimately makes us appreciate their culture.

\section{Result and Discussion}

Lontaan's book "Sejarah Hukum Adat dan Adat Istiadat Kalimantan Barat (The History of Traditional and Customary Laws of West Kalimantan)" (1975) is divided into three major sections: (1) History of the Kingdoms in West Kalimantan, (2) Customary Law, and (3)

12 | VOL. 10 NO. 1 JUNE 2021 
Customs. The contents of the third section can be divided into: (a) Religious Structure; (b) Dayak Kendayan Death Custom; (c) Dayak Kendayan Burial Custom; (d) Ceremony of Removing Dayak Graveyards; (e) Harvest Celebration; (f) Dayak Kendayan Marriage Customs; (g) Dayak Iban Customs; (h) Tattoos; (i) Tolak Balak; (j) Menayau; (k) Pancak; (1) Kadiaman; (m) Balenggang; (n) Traditional Sambas Regional Marriage (Malay); (o) Daya Linoh Traditional Marriage Ceremony; (p) Guest Welcoming Ceremony; (q) Traditional Rooster Fighting; and (r) The Hidden Harata in Nata Murau.

This present article does not examine the entire content of Lontaan's book (1975), but rather focuses on his discussion of the religious structure of the Dayak people who inhabit West Kalimantan, especially the interior areas. This is because the religious structure of the Dayak was thought to have been influenced by Hinduism as the results of inevitable encounters between natives and immigrants. It is widely known that eventhough the Dayak in West Kalimantan have embraced religions originating from outside, such as Christianity (Catholicism and Protestantism) and Islam, but they still practice and preserve local or ancestral religions and the customs as their ways of life. The Dayak who have embraced Islam no longer want to be referred to as Dayak, instead choosing to be called Malay because the latter is associated to Muslims who live in coastal areas.

Lontaan divides the theological structure of Dayak belief into three levels: (1) the highest divinity, who is further divided into two parts: (a) the god who inhabits the upper realm and (b) the god who inhabits the lower realm; (2) the highest form and manifestation of divinity; (3) intermediate gods, including (a) Raja Pali, (b) Raja Otong, (c) Raja Sial, (d) Raja Hantuen, and (e) Raja Peres. Lontaan also gives an 
The Traditional Religion...

account of Dayak doctrines about spirits, which he divides into (a) good spirits, (b) evil spirits, and (c) ancestral spirits.

All religions be it native to Indonesia or comes from overseas both contain a concept of God, and so does Dayak belief system.

\section{The Dayak View of the Supreme Being (God)}

According to Lontaan (1975), the concept of God or the Supreme Being of the West Kalimantan Dayak consists of two components: (1) the god who inhabits the upper realm, and (2) the god who inhabits the lower realm.

a. The God Who Inhabits the Upper Realm

Lontaan observes that the West Kalimantan Dayak believe in the existence of a god who inhabits the upper realm. This god is believed to possess a great power offered by the gods who inhabit the lower realm. The upper realm here can be called sky as well as otherworld. For the people of Ngaju, the god who inhabits the upper realm is called 'Tasik Tabenteram Bulau, Laut Babandan Intan' (Lake of Golden Sheen, Sea with Diamond Bridges). To explain the concept of this god, Lontaan cites the opinion of Carl Schwaner (a Dutch scholar), who translated the word bulau into Dutch as de zee, die door de maan bewogenwordt en de omgeeft (sea, which is shaken by the moon and surrounds it). Lontaan writes that Schwaner's translation is somewhat inaccurate due to his rendering of bulau as "moon." According to Lontaan, while the word bulau does indeed mean "moon," here its signification is closer to "gold" or a precious metal (Lontaan 1975: 450). As gold or a precious metal, it can be interpreted as a symbol of good fortune for human beings. In the Chinese-Hakka community in 
Singkawang in West Kalimantan, gold is also considered as a symbol of luck (Tanggok 2016:138).

Lontaan creates a term for God believed by the Dayak people as Divinity (Keilahian). The word Keilahian used by the Dayak to refer to their God is similar to the term Allah used in Islam.

"The divinity inhabiting the upper realm has at least four names, two of which are purely Dayak (local) names, while the other two evince external influences, namely, from Hinduism and Islam. The names are: (a) Bungai or Tingang, which are two names for the same bird, is a magical bird in the mythology of the Dayak people that is male. This magical bird symbolizes divinity in the realm above; (b) Raja Tontong Matanandau, Kanarohan Tambing, and Kabenteran-Bulan (King of the Corners of the Sun, Prince of the Fullness of the Moon); (c) Mahatara, who in the chant is called 'balian', usually 'Ranying Mahatara Langit.' Here we can see the influence of Hinduism, since it is closely related to two well-known words, Maha Brata. In the language of the Dayak of Danum tribe, it is called Pohotara; (d) Mahatala, who is colloquially referred to as Hatala, Lahatala or Alatala. This name shows the influence of Islam in which the name Allah Ta'ala is employed. Although there are similarities in terms of God in Dayak religion with [God in] Islam, the character of gods in other religions has absolutely no influence on the beliefs of this tribe, [just] like the influence of Hinduism with the name Mahatara."(Lontaan 1975: 451).

Whether or not the terms Lahatala or Alatala relates to or derives from the concept of Allah Ta 'ala in Islam or whether it is a similar concept between Islam and Hindu, further studies are much needed.

b. The God Who Inhabits the Underworld

In addition to believing in a god who inhabits the upper realm (Lahatala), the West Kalimantan Dayak also posit the existence of a god who inhabits the lower realm. The names of the two gods are different, and the names for God also vary from one Dayak ethnic group to another. The Bukit people who live in the mountains of Meratus in South Kalimantan refer to God as the creator and sustainer of human beings with the term "Hiyang Kuasa" (Radam 1987: 246). 
The Traditional Religion...

The Dusun and Murut who live in the interior of North Kalimantan refer God as the creator of mankind and this world with the term "Kinaringan" (Rutter 2017:385). However, the Dusun and Murut do not understand Kinaringan as a set of gods who control the upper and lower realms. Rather, in their view, Kinaringan rules over both the upper and lower realms. Lontaan also notes that the West Kalimantan Dayak assert the existence of gods in both the upper and lower realms.

"The Dayak Ngaju people who live in West Kalimantan call the god occupying the underworld 'Basuhun Bulau, Seramai Rabia' (The Golden River of Flowing Wealth). The expertise (god) inhabiting the underworld is called Tambon. According to Dayak mythology, Tambon symbolizes divinity and is female” (Lontaan 1975: 451)

According to Lontaan, all West Kalimantan Dayak usually request fertility or offspring from the god inhabiting the underworld.

"The god who inhabits the underworld is generally seen by the Dayak as a mother and is given the name 'Bawin Jata Balawang Bulau' (Jata Woman with Diamonds). This is another name for the god who inhabits the underworld. In everyday language, Bawin Jata Balawang Bulau is called Jata, whereas amongst the Dayak Maanyan clan Jata is called Diwita" (Lontaan 1975: 451)

Lontaan remarks that the word Diwita used by the Dayak represented an influence of Hinduism as indicated by the word Deva or Devata used to signify deities. Therefore, some believe that Dayak religion, which is often called Kaharingan, is a part of Hinduism or what is more popularly known as Hindu Kaharingan. But others argue that Kaharingan and Hinduism are different. To signify "cremation", the Dayak use the term Tiwah while the Balinese employ the term Ngaben. Maybe this is one reason why people think that Hinduism and Kaharingan are similar. 


\title{
The Concept of God's Existence
}

Lontaan explains that although in the view of the West Kalimantan Dayak Ngaju God has two components (a god who inhabits the upper realm and another who inhabits the lower realm), they exist together as a single, complete divine essence, especially in the process of creating the world and everything in it.

\begin{abstract}
"In the view of the Dayak Ngaju, Mahatara and Jata work [together] to create the heavens, earth and humans. They are also together in managing nature to ensure that it operates normally. These two highest gods have their respective totem emblems: tingang and spear is that of Mahatara while tambon and kris is that for Jata. In the religious thought of the Dayak Ngaju, the supreme God is conceived of anthropomorphically: Mahatara as a man and Jata as a woman. However, they never expressed this in pictures, sculptures, or paintings. The supreme divinity is always expressed in the form of its totem emblems, such as spears and kris, tall birds and tambon dragons. His presence is also not conceived of pantheistically" (Lontaan 1975: 452).
\end{abstract}

Unlike this concept of the supreme God espoused by the West Kalimantan Dayak Nganju, the Bukit people in South Kalimantan believe that the world is filled with gods who can control and sustain humans. Just like human homes, basic human necessities, flora, fauna, mountains, nature, animals, plants, mountains, rivers, and objects considered sacred all have their respective gods, who are all equal (Radam 2001: 25). Therefore, while Dayak Bukit rely heavily on such subordinate gods, the West Kalimantan Ngaju are very dependent on the gods of the upper and lower realms.

\section{Intermediate Gods (Ilah-Ilah Pengentara)}

Lontaan also observes that the West Kalimantan Dayak strongly believe in the existence of intermediate gods. The task of the intermediate gods is to connect human beings to the highest gods, which must be accomplished through a ceremony. 
"In the view of the Dayak people of West Kalimantan, the highest God is not one but [rather] consists of two [components], namely, "Tambon" or Mahatara and Bawin Jata Balawang Bulau, often called "Jata". These two gods are one inseparable unity because they cannot work separately, and [so they] carry out tasks together. Although in theory the Dayak people of West Kalimantan cannot have direct contact with the highest gods, because they have to go through the visible gods first, indirectly when they come into contact with the intermediate gods in the underworld they are automatically also connected with the upper realm" (Lontaan 1975: 453).

As Tanggok (2016) points out, the ceremony in this context functions as a link between the worshiper and the worshiped, or between human beings and gods, or gods serving as intermediators between humans and the highest god. Lontaan also takes note of the facts that of the many visible gods that can have a direct connection to human beings, only a few are considered to be chief gods. The number of these chief gods whom the Dayak believe in is five, and they are also known as the 'Five Kings' namely : (1) King Pali, (2) King Otong, (3) King Shit, (4) King Hantuen, and (5) King Peres. These five gods are called kings because they were chosen to be the chiefs of the other gods.

"In the Dayak community of West Kalimantan, Raja Pali is considered to be a god who possesses the speed of lightning. If there is a violation of the Pali laws (taboo laws), he acts swiftly. He participates in customary law trials. He also renders legal decisions in the customary law trials through the officers of the Head of Customs and his assistants called Mantir", (Lontaan 1975: 453).

Therefore, whatever decision is made by kepala adat (adat leader) in the customary law trials does not originate entirely from him; rather, there is also the involvement of Raja Pali.

"The Dayak of West Kalimantan believe that Raja Otong is a king in charge of granting sustenance. The full name of Raja Otong is 'Raja Mandulat Bulau, Kanarohan Bantuang Hintan Raja Balawang Bulau Kanaroham' (King of Gold Maker and Diamond Fence, Prince Creator of Diamonds, King of Gold Fenced in Diamonds) (Page 454)." Judging from this name, it seems that King Otong was a very 
wealthy king and [thus] is rightly believed to be the king of sustenance”. (Lontaan 1975: 454).

"Raja Sial is considered by the Dayak to be a very dangerous king. He is also known as "Tamang Tarai Bulan, Tambon Panton Garantong" (Tambon, A Copper Moon Batter and Gong Player). His function can be to cause dread, cruelty, accidents, losses, and even death. He is believed to reside in "Handut Nyaho, Kereng Tatabat Kilat” (Mount Guntur, Proof of Mountains Filled with Lightning) (Lontaan 1975: 454)

Given his place of residence, Raja Sial is viewed as an extremely dangerous god because he can provoke human dread and is very powerful. Therefore, many Dayak are afraid of him because he can bring sudden calamities upon human beings. In addition to Raja Sial, Raja Hanteun is also believed to wreak havoc.

"Raja Hantuen is seen as a source of corruption in the world. In the Balian song (a ceremonial song), he is also referred to as "Raja Haramuang Batolang Buno, Balikur Talawang" (The King of the Spear-Boned Tiger and the Backbone of the Shield). He is likewise seen as a source of unrest in the world; [he] can disturb and destroy humans. He is thought to be able to harass humans by drinking human blood (Lontaan 1975: 454).

Because of this conception, human beings are terrified of Hantuen and avoid performing actions that might provoke his anger. Lontaan also notes that in Dayak belief there is a chief of the four kings who can cause disease.

"Raja Peres, who is acclaimed as the chief of the previous four kings and believed to be the source of all illnesses. In accordance with his name Peres, which means 'disease', he can give rise to all diseases in humans. During an infectious disease pandemic, people most certainly believe it came from Raja Peres" (Lontaan 1975: 454).

Since the Dayak assert the existence of five kings, they cannot all be equal; one of the kings must be superior to all the others. Thus, Raja Peres was chosen as the chief of the five kings who rule over human life. Hence, he is greatly feared by human beings, and his heart must be 
The Traditional Religion...

pleased or persuaded. Pleasing his heart must be done with a series of ceremonial activities.

\section{Good and Evil Spirits or Gods}

a. Good Spirit or Gods

The West Kalimantan Dayak believe not only in the existence of the highest gods and gods who mediate between between human beings and the highest gods, but also in good and evil spirits or gods. Lontaan mentions four good spirits that West Kalimantan Dayak believe namely: (a) Tempon Telon, (b) Sangumang, (c) Atang Bejala Bulau, and (d) Jarang Bawahan.

“(A) Tempon Telon is considered a good god [and indeed] an allimportant god because he functions as an escort for the spirits of people who have died so that they can safely reach the spiritual realm where they are intending [to arrive]. Tempon Telon is a kind spirit and happy to help the spirits of people who have passed away reach the afterlife (or in Dayak Ngaju terminology, "Lewu Liau”). (b) Sangumang is a god very loved by the Dayak people, especially the Dayak Ngaju. If people have difficulties in life, they will certainly come to him for help. (c) Atang Bejala Bulau, [whose name] can be interpreted as "Golden-Tongued Eagle". This god is thought to be able to give a sign. The sign can be good or bad. He not only can offer a sign or indication but also provide help to humans if it is needed. In the Dayak community of West Kalimantan, Atang Bejala Bulau is adored and plays an important role in the daily life of the Dayak people. (d) Jarang Bawahan is seen as a god who can confer strength and heroism. He is also believed to be an almighty god, manly and possessed of extraordinary physical strength. Therefore, many people ask him for strength and heroism" (Lontaan 1975: 455).

These four gods have different characteristics and functions. The requests of the Dayak must be in accordance with the specialization of the god whom they are asking for help. If the Dayak want strength and heroism, they have to ask Jarang Bawahan. If they ask Atang Bejala Bulau for strength and heroism, it is possible that their request will not be granted because its target is considered to be wrong. It can be said that not a single deity whose existence posited by the Dayak can be 
held accountable for all their wishes. In other words, just like humans, these gods have their own limitations.

\section{b. Evil Spirits or Gods}

Lontaan argues that the West Kalimantan Dayak not only believe in good spirits or gods, but also in the existence of evil gods. Good spirits are thought to be happy to help human beings and the living members of their families, while evil spirits are considered to be gods or spirits that always disturb and threaten human life.

"The evil spirits can be enumerated as four: (a) Kuniak (Kuntilanak), believed by the Dayak community to be a spirit that likes to disturb pregnant women or women giving birth. (b) Keriau (Kerian), believed to be a god or spirit who has a small body and a habit of misleading and hiding people in the forest. (c) Kloe, an evil spirit or god who is considered sacred or holy and whose duty is to guard the land. Those who violate the taboo on the sacred land will be bothered by Kloe. People bothered by Kloe are called "buah pehingen". (d) Kukang, the spirit whose task is to test and prevent the spirits of the deceased from going to Lewu Liau (the final resting place). If a human always do good during his life, he overcomes the disturbances and obstacles of Kukang. On the contrary, if he always acts evilly during his life, he will be subject to a mighty punishment from Kukang" (Lontaan 1975: 455).

As mentioned above, Kuniak or Kuntilanak is very popular among the people of West Kalimantan as well as people outside of that region. Some people contend that the name of the capital of West Kalimantan, "Pontianak", is taken from the name of the spirit "Kuntilanak" believed to take pleasure in disturbing pregnant or laboring women. In addition to Kuntilanak, the spirits Keriau, Kloe and Kukang are also greatly feared by the West Kalimantan Dayak. In order to avoid being troubled by these four spirits, a ceremony to pleasure and persuade the hearts of the spirits is always performed.

The Dayak Ngaju also think that the natural environment surrounding human beings is filled with spirits (ganan in their language), who they believe occupy house poles, large stones, big trees, thickets, water, 
The Traditional Religion...

mountains, and other things located near human communities. These spirits have their own designations based on where they live, all of which can be classified as belonging to one of two groups, namely, the good spirits or the evil spirits. According to Dayak Ngaju, the good spirits are sangiang and nayu-nayu, while the evil spirits are Ngaju Taloh and Kambe (Danandjaja in Koentjaraningrat, 1993:138)). Not only the Kaharingan (the name of the Dayak religion) people who regard mountains as sacred places and dwelling places for spirits, but there are also many people outside Indonesia who regard mountains as sacred places, pilgrimages and tours. As said by Berner that the mountains are well known from all over the world, especially as places for pilgrimage. Classical phenomenology of religion used to present them as places of a hierophany and/or as spaces for a numinous experience (Berner 2020: 18-30).

\section{c. Ancestral Spirits}

Lontaan writes that the death of family members in the West Kalimantan Dayak community does not bring an end to the relationship between the living and the dead. Instead, these two still maintain good relations despite occupying different realms. This good relationship between the two will continue indefinitely.

"First, there is a connection between the living and the dead/the spirits of their ancestors. The Kayaan people also believe that there are two worlds of life with their own communities, namely, the community of the living in this world and the community of the dead who live on the other side (Telaangjulaan)/the world of spirits. Second, in this conception, Tanangaan cannot be approached directly, but only through the intermediary of the spirits of their own ancestors. They believe that it is the spirits of their ancestors who can directly connect to God. These ancestral spirits convey the desires of the living to God. Because they are generally Catholic, the God they refer to is God the Father. Third, Tanangaan is God the Father as found in the Catholic religion they follow, with His characteristics as a creator. In the ceremony they sacrifice a pig. From the perspective of the Kayaan Dayak belief system, one's request is granted through a sign given by 
God in the organs of a slaughtered pig. Pigs are seen as a ceremonial requirement offered to God" (Lontaan, 1975: 456).

The Dayak Maanyan belief system in Kapuas Hulu District in West Kalimantan is no different from Dayak Kayaan (they also live in the Kapuas Hulu district). The Dayak Kayan people view their ancestors as representatives between family members and God (Kristianus 2017: 87-93). In his work, Lontaan sees Dayak Kayaan people about ancestral spirits also bear similarities with the beliefs of the Dayak Maanyan in about their ancestors, whom they think exist in another world and are capable of managing the lives of their family members in this world. In connection with these Dayak Maanyan ancestral spirits, Lontaan quotes R.J. Mallingkrodt (in Lontaan 1975: 456), who explains that:

"The Dayak Maayan people's belief in the spirits of their dead ancestors is seen as [a form of] "handhavers van het gewoonterecht" (law enforcers in society). The Dayak Maanyan people believe in the existence of the spirits of their ancestors called "Ngaju Saniang". They also think that the spirits of these ancestors can only get to Lewu Liau if their family members fulfill the requirements of the death ceremony completely and perform it well. Afterwards, the living relatives can ask the spirits of the new ancestors for help. These ancestral spirits can also function as protectors, village or river guards, or special guards for a family. In the traditions of the Dayak Maanyan people in West Kalimantan, these ancestors are provided with special places for worship, such as trees, stones, and statues (called hampatong), which are specially designed [for others] to worship them. They believe that the spirits of their ancestors reside in the stones and statues." (Lontaan 1975: 456).

The Dayak Maanyan tradition of preparing ancestral shrines is similar to the practice of Chinese people, both in and outside of China, of furnishing a place to worship their ancestors at home, that is, an altar for ancestral worship (Tanggok 2005:105). This tradition of worshipping ancestor in Chinese society has passed down from generation to generation and continues to this day. This Dayak 
Maanyan belief also has similarities with the practice of Buddhist rituals in Japan, where worship is not only done for the Amida statue, but is also done for monk and nun spirits at the home altar where they are also offered flowers (Gillson 2019: 31-51).

Lontaan states that the Dayak Maanyan hold an opinion that the spirits of their ancestors can reside in trees, stones, statues and other sacred places, for which reason ceremonies are always conducted in front of these objects.

"Apart from trees, stones and statues as places for the worship of their ancestors, Dayak Maanyan people also often construct small houses on single poles and place them in the middle of the house, which is believed to be the abode of their ancestral spirits. Obtaining objects such as stones, trees, jars and others thought to constitute the dwelling places of the spirits of their ancestors is usually done in two ways: (1) through dreams and (2) through meditation. Here Lontaan also tells how the Dayak get these sacred items through meditation (known as "batarah" in the Dayak Maanyan language). He describes the process as follows: Some people (there can be three) are assigned by the village community to look for objects or materials that will be blessed by the spirits of their ancestors to become their dwelling places. The search for these objects is carried out by meditating for seven days and seven nights in a hut outside the village. During their meditation, they are allowed to eat only sticky rice with salt. If they transgress, the ascetic procedure and search for holy objects are considered to have failed. After seven days and seven nights, the retreat is complete, so they can walk in the area around the hermitage to find the desired object. If in the process of searching they find an object considered strange, such as a stone, which according to their intuitions signals itself as a suitable place for worshipping [their ancestors], then they can stop there and spend the night at that location." (Lontaan 1975: 456)

"If they (the people who are tasked with meditating) have a good dream -while spending the night at the location where the objects believed to house the ancestral spirits were found-then this dream can be interpreted as the blessing of their ancestors to bring the object back to their village and keep it, and that thing is what they have to take back to their village in order that it be made into a place for worshipping [them]. Before taking the object back to the village, they first slaughter the sacrificial animal and have its blood smeared all over the outside of the object. Then [they] cook the sacrificial meat and add a little rice. The rice and retrieved objects are placed on the 
"ancak" (a structure made of coconut leaves and used as a place for offerings). The ground around the object is lined with a knife while certain ritual incantations are chanted to request permission from the earth to bring the retrieved object home. This object is then brought back to the village and serves as the object of several kinds of rituals. After the ritual is carried out, the object is considered a center of worship and a place to offer sacrifices for the spirits of the ancestors believed to live in the object and respond to all of their requests (Lontaan 1975:457)."

This is the process when objects found during the retreat are made into instruments for worship that believed to be the place where ancestral spirits reside. For the Dayak Maanyan, there are spirits watching over every place where items considered sacred are located; thus, people cannot simply take things from a certain place (from the forest for instance) without first asking the permission of the spirits exercising power over the objects. If they do not ask permission, the spirits in control of that place will become angry, and so it will be dangerous for people to take the objects.

By virtue of their belief in ancestral spirits, the Dayak Maanyan can be considered as animists, i.e. people who believe in the existence of spirits and ancestral spirits. Yet, their belief that ancestral spirits may live in certain objects can be classified as dynamists, i.e. a belief that objects have spirits. In the Macmillan Dictionary of Anthropology, animism is defined as "the belief that natural phenomena are endowed with life or spirit, or the tendency to associate supernatural or spiritual characteristics with plants, linking with geological characteristics, climatic phenomena and so on," (Smith 2003: 12).

Similar to the Dayak Nganju and Dayak Maanyan, the Dayak Dosan in West Kalimantan meet their daily needs through farming. They also believe that nature, including the forest, contains spirits, and these spirits can act both in accordance with and in opposition to human 
The Traditional Religion...

desires. For this reason, before going to work in the fields they perform rituals so that the spirits do not interfere with their activities, and so that they help them to attain an abundant rice harvest every year, or at least one that fulfills their expectations (Hartati 2008:35). To persuade and please the spirits, people conduct ceremonies. As Radam (2001:29) points out, the ceremony is both an attempt to prove the accuracy of the belief of a person or group of people in something and a confirmation of that belief. Like the Dayak Maanyan and the Dayak Dosan, Dayak Gerondang in Ketapang Distrik in West Kalimantan also believe in spirits and the power of spirits in casting away the evils (Tanggok 2004: 171).

The belief in the existence of ancestral spirits is also found amongst the Kwaio (in the Solomon Islands), who believe that their world is controlled by ancestral spirits known as adalo. Adalo are believed to be able to communicate with living family members (Havilland 1993: 287). Like the Melanesian Kwaio people, the Chinese also known to worship their ancestors. As Yang (1961:31) explains, ancestor worship in Chinese society is basically a means of coping with the emotionally devastating and socially disintegrating events resulting from the death of a nuclear family member in a family group. The living can develop very deep emotional, social and economic dependence on the dead, especially if the deceased were adults (i.e., fathers and mothers) who raised their families.

Such are the doctrines about God, spirits or gods, ancestral spirits and life after death espoused by the West Kalimantan Dayak as described by Lontaan in his monograph that is under study. These doctrines are still developing in the daily life of the Dayak to this day, even though 
many of them have embraced religions that originate from other regions.

\section{Conclusion}

In conclusion, there are at least two points highlighted from Lontaan's work. First, Lontaan's main observation indicates that the Dayak still maintain their ancestral culture, which includes rituals based on their beliefs in spirits, ancestral spirits, and God, as well as customary laws. Those who have converted to Islam no longer practice the customs and rituals related to ancestral spirits and spirits that contradict Islamic teachings. The difference between Lontaan's work and that of other preceding anthropologists such as Radam is that Radam focuses more on studying the culture and religious beliefs of the Dayak Bukit people in South Kalimantan. The same is true for Rutter, who in his book also concentrates on one South Kalimantan ethnic groups, including its culture and religious beliefs. In contrast, Lontaan does not only examine one Dayak ethnic group, but also the culture and religious beliefs of the Dayak Kanayatn, Kayan, Maayan and other Dayak tribes in West Kalimantan, and he compares their customs with one another. Second, Lontaan argues that by studying the ethnic groups of West Kalimantan and understanding their culture, customs, religious beliefs and ways of life, we respect people who are different from us and treat them as equals. There are three novelties of Lontaan's work, first he tries to describe and understand not only the culture and traditional religion of the Dayak, but also that of two other major ethnic groups (Malay and Chinese) in West Kalimantan. Second, Lontaan's work is not only categorized as a historical, anthropological, or legal work, but can also be categorized as theology work. This is due to the fact that, in analyzing the customs of the Dayak people, Lontaan used verses from 
The Traditional Religion...

the Bible. Third, Lontaan's work can be used as an analytical tool in studying and understanding Dayak's cultures today.

\section{References}

Berner, U. (2020). Mountains as sacred spaces. Jurnal STKIP BJM, 2, 1-13. $\quad$ https://www.jurnal.stkipbjm.ac.id/index.php/ocspbsi /article/view/938.

Darmadi, H. (2017). Dayak Asal-Usul dan Penyebarannya di Bumi Borneo (1). Sosial Horizon: Jurnal Pendidikan Sosial, 3(2), 322-340.

Geertz, C. (1960). The Religion of Java (- (ed.); 1st ed.). USA: The Free Press of Glencoe, a Corporation.

Gillson, G. (2019). Traversing the Nenbutsu The Power of Ritual in Contemporary Japanese Buddhism. Japanese Journal of Religious Studies, Japanese Buddhism. 46(1), 31-52. Nanzan Institute for Religion and Culture $\mathrm{dx}$, 31-52, doi.org/10.18874/jjrs.46.1.2019.31-51.

Havilland, W. A. (1993). Antropologi. Jakarta: Penerbit Erlangga ( $2^{\text {nd }}$ ed).

Heidhues, M. S. (2003). Golddiggers, Farmers, and Traders in the" Chinese Districts" of West Kalimantan, Indonesia. Cornell University Press.

Keesing, R. M. (1975). Cultural Anthropology: A Contemporary Perspective (1st ed.). Holt, Rinehart, and Winston.

Koentjaraningrat. (1993). Manusia dan Kebudayaan di Indonesia. Jakarta: Jambatan (14th ed.).

Kristianus. (2017). Dialektika Budaya Dayak: Enkulturasi Agama Katolik dengan Budaya Dayak Kayaan. Jurnal Studi Kultural, Volume II (Sekolah Tinggi Agaka Katolik Negeri Pontianak), 87-93. https://journals.an1mage.net/index.php/ajsk.

Lontaan, J. U. (1975). Sejarah, Hukum Adat dan Adat Istiadat Kalimantan-Barat. Pemda Tingkat I KalBar.

Orong, Y. (2020). Corn \& Arak (Local Alcohol) as an Alternative to Bread \& Wine in the Catholic Ritual of the Eucharist (A Deconstructive Analysis of the Novel "Lembata"). Heritage of Nusantara: International Journal of Religious Literature and Heritage, 9(2), 2020. 165-193.

28 | VOL. 10 NO. 1 JUNE 2021 
Radam, N. H. (1987). Religi Orang Bukit: Suatu Lukisan Struktur Dan Fungsi Dalam Kehidupan Sosial-Ekonomi. Yogyakarta: Yayasan Semesta.

Rutter, O. (2017). Sejarah Kalimantan (1st ed.). Penerbit Indoliterasi Group.

Saeffudin. (2019). Kearifan Tradisi Masyarakat Dayak Deah di Kalimantan Selatan. (Traditional Wisdom of the Dayak Deah Community in South Kalimantan). Tuah Talino, 253-269. Tahun XIII Volume 13 Nomor 2 Edisi 6 Desember 2019.

Smith-Seymour, C. (2003). Palgrave dictionary of Anthropology. Macmillan International Higher Education.

Hartati, Sri. (2008). Relasi Antara Religi Dengan Sistem Perladangan Masyarakat Dayak Dosan Kalimantan Barat. Yogyakarta: Fakultas Ushuluddin, UIN Sunan Kalijaga Yogyakarta.

Sulistyowati, E. (2020). Wujud budaya masyarakat Dayak Meratus pada Novel Catatan Ayah Tentang Cintanya Kepada Ibu karya Sandi Filry dan Kontribusinya Terhadap Pembentukan Karakter Generasi Milenial. Https://Www.Jurnal.Stkipbjm.Ac.Id/Index. Php/Ocspbsi/Article/View/938, 2(2019).

Sumaryono, E. (1996). Hermeneutik Sebuah Metode Filsafat. Yogyakarta: Kanisius (- (Ed.); 1st ed.).

Suminto, et al. (2017). Potret Perempuan Dayak Iban, Kayan, Desa, dan Sungkung di Kalimantan Barat. Specta: Journal of Photography, Arts and Media, 1(1), 51-66.

Suparlan, P. (1991). The Javanese Dukun. Jakarta: Peka Publications.

Tanggok, M. I. (2005). Upacara Pemujaan Leluhur Orang Hakka di Singkawang (1st ed.). Jakata: Pukat.

Tanggok, M. I. (2017). Agama dan kebudayaan orang Hakka di Singkawang: Memuja leluhur dan menanti datangnya rezeki. Jakarta: Buku Kompas.

Tanggok, M. Ikhsan. (2004). Menembus Birokrasi Indonesia (- (ed.); 1st ed.). Jakarta: PT. Gramedia Pustaka Utama.

Victor Turner. (1974). The Forest of Syimbols, Asfects of Ndebu Ritual. Ithaca dan London: Cornell University Press.

Wallace, A. F. C. (1966). Religion: An Anthropological View. New York: Random House. 
The Traditional Religion...

Yang, C. K. (2020). Religion in Chinese society (1st ed.). Amerika: The Regents of The University of California.

Yusriadi. (2018). Di Kalimantan Barat Identity of Dayak and Melayu. 1(2),1-16. https://www.researchgate.net/publication/331237584 _IDENTITAS_DAYAK_DAN_MELAYU_DI_KALIMANTA N_BARAT/link/5c6e017c299bf1e3a5b8d011/download. 
Sejarah Hukum Adat dan Adat Istiadat Kalimantan Barat

Author: J.U Lontaan.

Date: 1975

Publisher: Pemda Kalimantan Barat

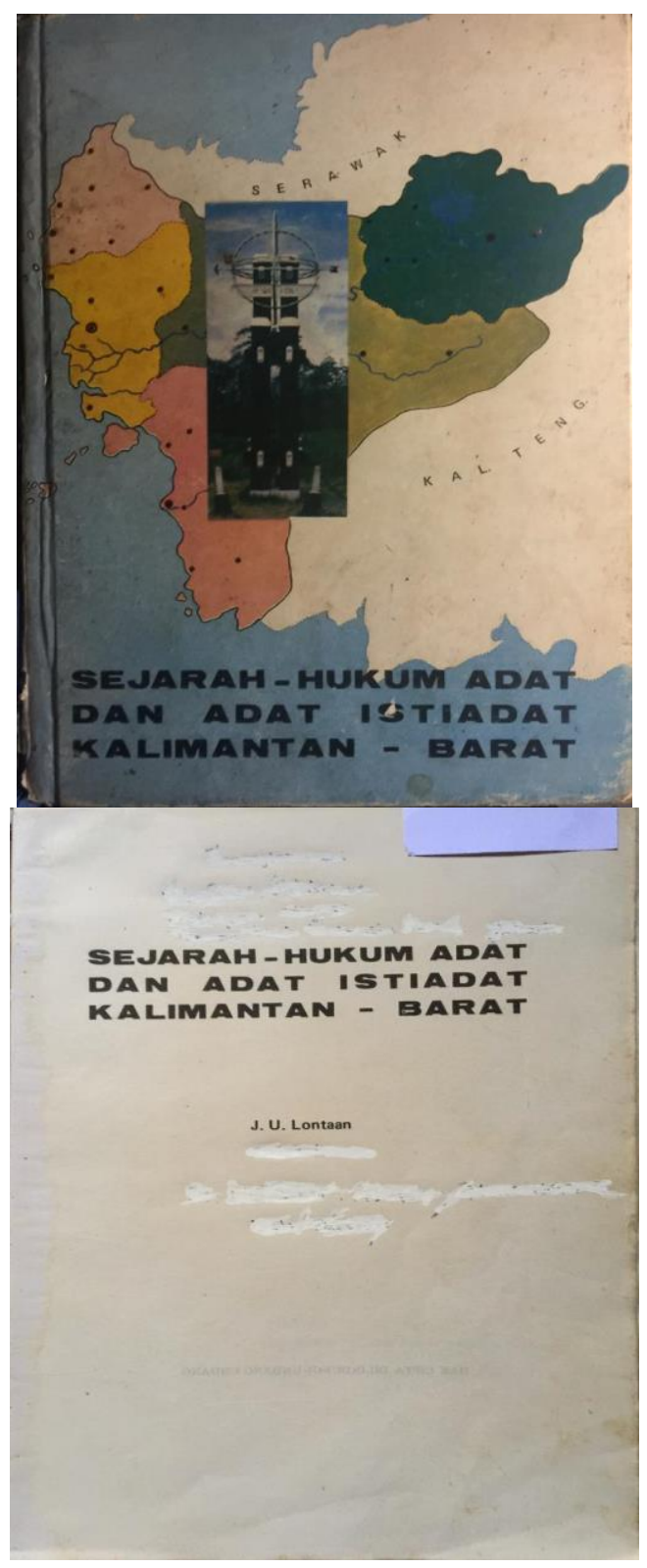

Heritage of Nusantara: 